\title{
IV. Âtizen.
}

\section{Entwurf eittes internationalen Dogelfđungefetzes.}

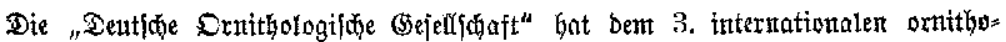

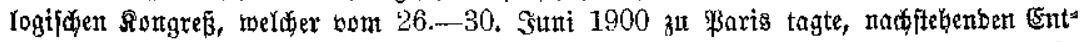

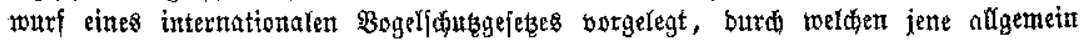
giltigen (s) lage bei bent ibrerjeitz zu gebenben Bogelidubgefezent als Direftiven zu bienem haben,

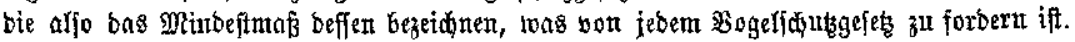

Die Sonmiffin, welde biejen Entmurf bearbeitete, wax zurfamntengefert alls ben

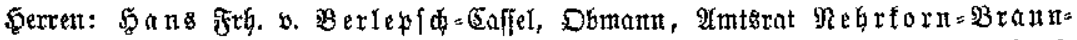

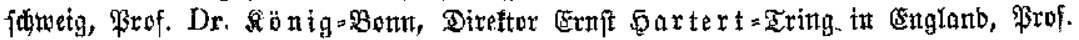

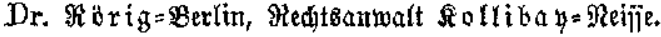

Der Entwurf lautet:

\$ 1. Serboten ift

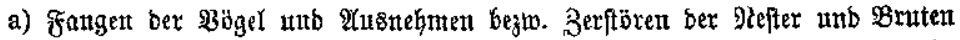
berjetben. Sebod bitrfen Refter, toeldie tid) an ober in (Gebänton ober in

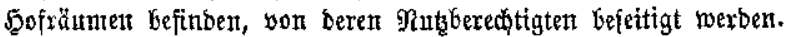

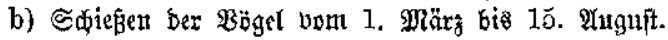

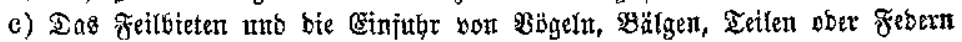

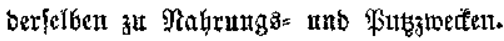

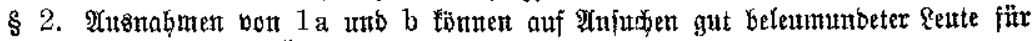

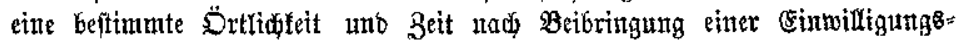
beldeinigung ber Befizer bez Grutto. ntto Bobents, fowie ber Sagbberectitiglen bort bert zuftäubigen Beb̈rben geftattet werben:

a) 3 ut mijenfonaftlithen 3 wetfen;

b) Bum Fang non GtubenbögeIn, infofern berjelbe nidat Mlaffenfang ift, imer balk ber Seit von 15. Wugnft Gis 1. Miär;

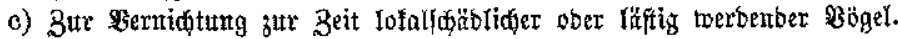

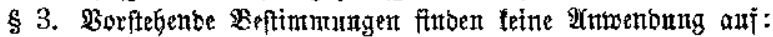

a) Das zahime Febervieb,

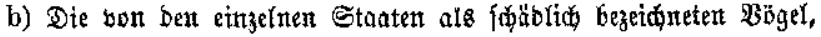

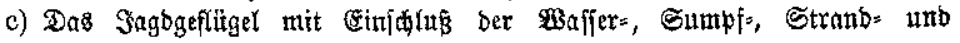
Şühner 2 B̈gel uno ber Taubent.

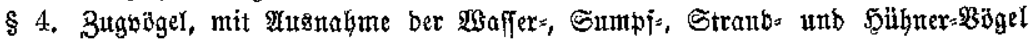

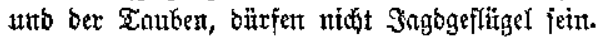

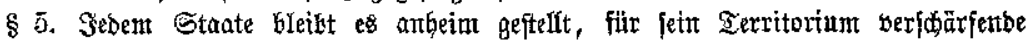
Sonberbeftinnungen gut geben."

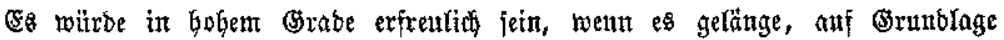

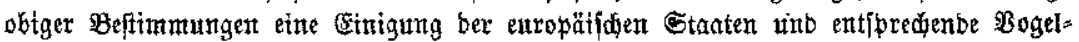

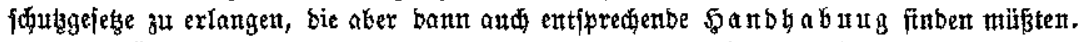

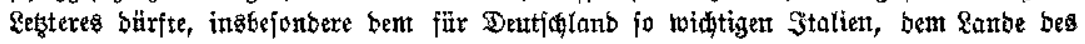
ssogelmaffenntorbes, gegentiber bie Sauptijatie jein. 